\title{
Concentration of main elements in mineral matter of Polish coking coal and its cleaning products
}

\author{
Krzysztof Bytnar $^{1, *}$, Dorota Makowska ${ }^{1}$ \\ ${ }^{1}$ AGH University of Science and Technology, Faculty of Energy and Fuels, Mickiewicza Av. 30, \\ 30-059 Cracow, Poland
}

\begin{abstract}
The chemical composition of coal mineral matter, and particularly the content of major elements ( $\mathrm{Al}, \mathrm{Si}, \mathrm{Fe}, \mathrm{Ca}, \mathrm{K}, \mathrm{Na}, \mathrm{Mg}$ ), plays an important role in the processing and use of bituminous coals. Mineral matter is the ballast, reducing the calorific value of the fuel. The aim of the study was to analyze the concentrations of main elements of coking coal mineral matter and products of its cleaning in heavy media, jiggers and flotation machines. Analysis of elements was performed through the technique of the atomic absorption spectrometry AAS. The results of main elements concentrations of coal mineral matter and its cleaning products are discussed in relation to each operation of mechanical treatment. As a result of the cleaning process in heavy media, the content of mineral substances decreased seven times, mainly due to the removal of components such as silicon, aluminum and iron from coal. Similar results were obtained in the case of cleaning in jiggers, leading to a significant reduction of the contents of silicates and aluminosilicates. In both cases, there was an increase in the content of sodium. Despite the significant reduction of the contents of alkali metals' compounds, their content in concentrates as converted to oxides is quite high $(0,43-0,81 \%$ of dry coal $)$. The lowest alkalis content is the displayed by a coal concentrate from the flotation process dewatered in a centrifuge.
\end{abstract}

\section{Mineral matter of coal}

Coals, in particular bituminous coals, due to their properties are a valuable natural resource with a variety of applications in a number of industries. In addition to coal combustion, this raw material is also used in processes like pyrolysis, gasification and liquefaction.

From the point of view of the processes during the thermochemical treatment of coal, the elemental composition of coal mineral matter plays an important role, in particular content of the so-called major elements ( $\mathrm{Al}, \mathrm{Si}, \mathrm{Ca}, \mathrm{Mg}, \mathrm{Fe}, \mathrm{Na}$ and $\mathrm{K}$ ) which determine the directions of processing and properties the final products.

The mineral matter contained in the coal is a ballast, causing a decrease in the calorific value, or in the case of coking coal causes deterioration of the coal coking

\footnotetext{
*Corresponding author: bytnar@agh.edu.pl
} 
properties. In addition, many compounds that occurs in the coal mineral matter (alkali, sulphur compounds, iron and magnesium) have a negative impact on the process of thermochemical processing of coal. The most common minerals occurring in the coal are the silicates, aluminosilicates, carbonates, sulfides, sulfates, oxides, hydroxides, halides and trace elements.

The above-mentioned alkaline compounds which mode of occurrence and negative effects have been discussed in several papers [1-3] cause, inter alia, lower the ash melting temperature. It can lead to the formation of agglomerates and closing the slats in coal boilers in the combustion process. In gasification processes alkaline compounds cause the formation of lesions in gasifiers reducing their efficiency. In the process of the pyrolysis about $40 \%$ of alkaline compounds passes to coke, being the source of the blast furnace accretions that breaking away of from the walls of the blast furnace leads to clogging of the nozzles and the blast furnace burnout. Therefore, the coke industry sets certain requirements for the content of alkali compounds in the coking coal, namely the sum of $\mathrm{Na}_{2} \mathrm{O}$ and $\mathrm{K}_{2} \mathrm{O}$ does not exceed 0,2 to $0,3 \%$ wt.

A significant part of coal mineral matter is aluminum ( $\mathrm{Al})$ and silicon $(\mathrm{Si})$. They are basic component of silicates and aluminosilicates. The share of silicate may be up to 40 to $60 \%$ of coal mineral matter (Table 1). Among the silicates, quartz and opal in $800^{\circ} \mathrm{C}$ transform the structure of its crystal lattice $-870^{\circ} \mathrm{C}$ quartz is converted to tridymite, and opal at $100^{\circ} \mathrm{C}$ loses water, and at high temperature it passes transformations similar to quartz.

Table 1. Examples of mineral components containing alkalis found in Polish coals [4].

\begin{tabular}{|c|c|c|c|}
\hline \multicolumn{3}{|c|}{ Name, description } & Formula \\
\hline \multirow{2}{*}{ 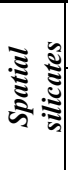 } & \multicolumn{2}{|l|}{$\begin{array}{l}\text { Potassium feldspars: } \\
\text { Orthoclase, microcline }\end{array}$} & $\mathrm{K}\left[\mathrm{AlSi}_{3} \mathrm{O}_{8}\right]$ \\
\hline & \multicolumn{2}{|c|}{$\begin{array}{l}\text { Sodium and Potassium feldspars (plagioclases): } \\
\text { albite } \\
\text { anorthite }\end{array}$} & $\begin{array}{l}\mathrm{Na}\left[\mathrm{AlSi}_{3} \mathrm{O}_{8}\right] \\
\mathrm{Ca}\left[\mathrm{Al}_{2} \mathrm{Si}_{2} \mathrm{O}_{8}\right]\end{array}$ \\
\hline \multirow[t]{2}{*}{ 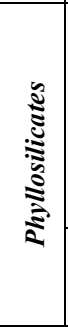 } & $\begin{array}{l}\text { Micas: } \\
\text { dioctahedral structure: } \\
\text { ordinary micas: } \\
\text { hydromicas } \\
\text { trioctahedral structure: } \\
\text { ordinary micas: }\end{array}$ & $\begin{array}{l}\text { muscovite } \\
\text { hydromuscovite } \\
\text { illite } \\
\text { biotite }\end{array}$ & $\begin{array}{l}\mathrm{KAl}_{2}\left[(\mathrm{OH})_{2} / \mathrm{AlSi}_{3} \mathrm{O}_{10}\right] \\
\left(\mathrm{K}, \mathrm{H}_{3} \mathrm{O}\right) \mathrm{Al}_{2}\left[(\mathrm{OH})_{2} / \mathrm{AlSi}_{3} \mathrm{O}_{10}\right] \\
\left(\mathrm{K}, \mathrm{H}_{3} \mathrm{O}\right) \mathrm{Al}_{2}\left[(\mathrm{OH})_{2} / \mathrm{AlSi}_{3} \mathrm{O}_{10}\right] \\
\mathrm{K}(\mathrm{Mg}, \mathrm{Fe}, \mathrm{Mn}) 3\left(\mathrm{OH}, \mathrm{F}_{2} / \mathrm{AlSi}_{3} \mathrm{O}_{10}\right]\end{array}$ \\
\hline & $\begin{array}{l}\text { Montmorillonites: } \\
\text { dioctahedral structure: } \\
\text { montmorillonites }\end{array}$ & $\begin{array}{l}\text { montmorillonite } \\
\text { beidelite }\end{array}$ & $\begin{array}{l}\left(\mathrm{Al}_{1.67} \mathrm{Mg}_{0.33}\right)\left[(\mathrm{OH})_{2}\left[\mathrm{Si}_{4} \mathrm{O}_{10}\right] \mathrm{Na}_{0.33}\left(\mathrm{H}_{2} \mathrm{O}\right)_{4}\right. \\
\mathrm{Al}_{2}\left[(\mathrm{OH})_{2}\left[\mathrm{Al}_{0.5} \mathrm{Si}_{3.5} \mathrm{O}_{1}\right] \cdot(\mathrm{Ca}, \mathrm{Na})_{0.5}\left(\mathrm{H}_{2} \mathrm{O}\right)_{4}\right.\end{array}$ \\
\hline : & \multicolumn{2}{|l|}{$\begin{array}{l}\text { Anhydrous chlorides: } \\
\text { halite } \\
\text { sylvine }\end{array}$} & $\begin{array}{l}\mathrm{NaCl} \\
\mathrm{KCl}\end{array}$ \\
\hline 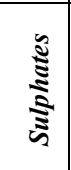 & \multicolumn{2}{|l|}{$\begin{array}{l}\text { Anhydrous sulphates: } \\
\text { alunite } \\
\text { natroalunite } \\
\text { jarosite } \\
\text { natrojarosite }\end{array}$} & $\begin{array}{l}\mathrm{KAl}_{3}(\mathrm{OH})_{6} /\left[\left(\mathrm{SO}_{4}\right)_{2}\right] \\
\mathrm{NaAl}_{3}(\mathrm{OH})_{6} /\left[\left(\mathrm{SO}_{4}\right)_{2}\right] \\
\mathrm{KFel}_{3}(\mathrm{OH})_{6} /\left[\left(\mathrm{SO}_{4}\right)_{2}\right] \\
\mathrm{NaFe}_{3}(\mathrm{OH})_{6} /\left[\left(\mathrm{SO}_{4}\right)_{2}\right]\end{array}$ \\
\hline 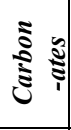 & \multicolumn{2}{|l|}{$\begin{array}{l}\text { Anhydrous carbonates: } \\
\text { calcite } \\
\text { dolomite } \\
\text { ankerite } \\
\end{array}$} & $\begin{array}{l}\mathrm{CaCO}_{3} \\
\mathrm{CaMg}\left(\mathrm{CO}_{3}\right)_{2} \\
\mathrm{CaFe}\left(\mathrm{CO}_{3}\right)_{2} \\
\end{array}$ \\
\hline 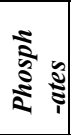 & \multicolumn{2}{|l|}{$\begin{array}{l}\text { Phosphates: } \\
\text { goyazite } \\
\text { crandallite } \\
\text { fluorine apatite }\end{array}$} & $\begin{array}{l}\mathrm{SrAl}_{3}\left(\mathrm{PO}_{4}\right)_{2}(\mathrm{OH})_{5} \cdot \mathrm{H}_{2} \mathrm{O} \\
\mathrm{CaAl}_{3}\left(\mathrm{PO}_{4}\right)_{2}(\mathrm{OH})_{5} \cdot \mathrm{H}_{2} \mathrm{O} \\
\mathrm{Ca}_{3}\left(\mathrm{PO}_{4}\right)_{3} \mathrm{~F}\end{array}$ \\
\hline
\end{tabular}


The clay minerals in a temperature range of $600 \div 800^{\circ} \mathrm{C}$ release water, kaolinite in $800^{\circ} \mathrm{C}$ converted to an intermediate form $\mathrm{Al}\left(\mathrm{AlSiO}_{5}\right)_{6}$ to end at $1100^{\circ} \mathrm{C}$ in the presence of fluxes to transform $3 \mathrm{Al}_{2} \mathrm{O}_{3} \cdot 2 \mathrm{SiO}_{2}$. A halloysite transformed in a similar way, while illite at about $1250^{\circ} \mathrm{C}$ melts and loses potassium. Calcium (Ca) is usually in the form of carbonates and sulphates (Table 1). Carbonates in terms of incidence in the coal seams are second. The most common carbonate is the calcite and its several polymorphic variants. Calcium is also included in the double anhydrous carbonates such as dolomite or ankerite. While on the sulphate anion calcium forms anhydrous calcium sulfate - anhydrite, and its hydrated form gypsum. The small amounts of calcium can combine with the phosphate anion of a series of minerals, so called apatites [4]. In the case of carbonates we can find a large range of thermal reaction. Siderite at a temperature of 450 to $500^{\circ} \mathrm{C}$ decomposes to magnetite, dolomite decomposes at $765 \div 895^{\circ} \mathrm{C}$ and calcite decomposes at $900^{\circ} \mathrm{C}$. The obtained $\mathrm{CaO}$ reacts with $\mathrm{SO}_{2}$, to next decomposed in higher temperatures again to $\mathrm{CaO}$ and $\mathrm{SO}_{2}$. Hydrated sulfates (epsomite, gypsum) lose crystalline water at about $400^{\circ} \mathrm{C}$, and the thermal dissociation of the anhydrous compounds occurs in $900^{\circ} \mathrm{C}$.

Iron $(\mathrm{Fe})$ is most common in combination with sulfur, mainly in the form of iron sulfides - pyrite, which is present both in free and bound form of mineral matter and can occur in its hydrothermal variety - marcasite. This was formed both by syngenetic transformation (at the same time as coal bed was formed) and as a result of epigenetic transformation (formed much latethan coal bed). As a result of the oxidation reaction of pyrite in the coal weathering, hydrated iron sulphates was formed - malanterite and jarosite, but they occur occasionally. Iron also rarely occurs in the form of iron sulphates and compounds with oxygen and a hydroxyl group (hematite and goethite). Iron sulfides decompose in $500^{\circ} \mathrm{C}$ giving as final products $\mathrm{SO}_{2}$ and $\mathrm{Fe}_{2} \mathrm{O}_{3}$. According to this scheme galena and sphalerite are transformed. With increasing temperature to $1000^{\circ} \mathrm{C}$ formed oxides are volatilized. Iron hydroxides dehydrate at $110 \div 150^{\circ} \mathrm{C}$ giving hematite, while aluminum hydroxide loses water in $600^{\circ} \mathrm{C}$ converts to corundum, but in contrast to the iron oxides does not go to volatilize at higher temperatures. The iron contained in the coal as a result of the pyrolysis process enters coke and in the temperature range of $600 \div 1000^{\circ} \mathrm{C}$ due to its catalytic effect increases the coke reactivity. Whereas both silicon and aluminum act as inhibitors reducing the reactivity of the coke to the temperature $800^{\circ} \mathrm{C}$.

Elemental sulfur goes into volatile at $444^{\circ} \mathrm{C}$, while the oxalates decompose above $800^{\circ} \mathrm{C}$ precipitate the coal. Halides (halite and sylvite) are volatilize at temperatures close to $1000^{\circ} \mathrm{C}$. Calcium phosphates are partially decomposed at about $800^{\circ} \mathrm{C}$, and their com In British English is « sulphate »plete decomposition occurs above $1300^{\circ} \mathrm{C}$. The last group of troublesome elements present in the coal are alkali: $\mathrm{Na} 2 \mathrm{O}$ and $\mathrm{K} 2 \mathrm{O}$ that are volatilize at a temperature of about $900^{\circ} \mathrm{C}$ and $\mathrm{CaO}$ passing under these conditions to sulfates and their subsequent transformation are similar as in the case of carbonates.

\section{Experimental}

The subject of the study was to analyze the content of major elements ( $\mathrm{Al}, \mathrm{Si}, \mathrm{Fe}, \mathrm{Ca}, \mathrm{K}$, $\mathrm{Na}, \mathrm{Mg}$ ) in mineral matter of coking coal and products of its beneficiation processes. The study focused on both, raw coking coal and the products of mechanical treatment from mines of the Upper Silesian Coal Basin (USCB). Taking into account all stages of coal preparation, individual products of coal cleaning was analyzed: raw coal (feed), concentrate, intermediate product and a waste from dense medium washers, jig washers and flotation. Three-product enrichment scheme implemented in the USCB mines processing plants shown in Figure 1.

The raw coal (grain size 0 to $120 \mathrm{~mm}$ ) is headed to the processing plant, where it is screened on a screen with a mesh of $20 \mathrm{~mm}$. Size grade: 20 to $120 \mathrm{~mm}$ is directed to 
cleaning in a dense medium washer (a specific weight of $1.45 \div 1.80 \mathrm{~g} / \mathrm{cm}^{3}$ ), and the coal having a particle size of $0 \div 20 \mathrm{~mm}$ is cleaned in water pulsating jigs. The smallest coal grain class of less than $0.5 \mathrm{~mm}$ from the dewatering of jig wash product undergoes to flotation and the resulting concentrate is drained centrifuges (or dried). Plants have a closed water-mule loop and the waste management after the flotation process. [5].

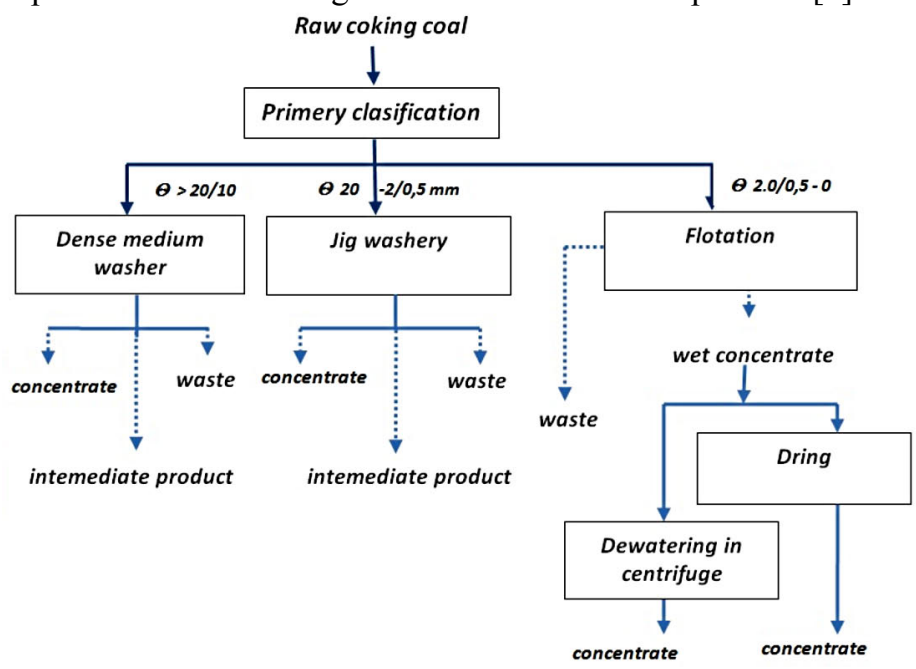

Fig. 1. The three-tier coking coal processing plants in Upper Silesian Coal Basin

Analytical samples (grain size $<0.2 \mathrm{~mm}$ ) of semi-soft coal (Polish type 34) and hard coal (Poilsh type 35), and its enrichment products, taken directly from coal processing plants of individual USCB mines, have been prepared. Samples with a weight of $0.15 \div$ $0.40 \mathrm{~g}$ were digested with acidic solution in microwave closed system using nitric and hydrofluoric acids. Digestion were performed in a microwave oven Berghoff Speedwave Four. The analysis of the elements $\mathrm{Si}, \mathrm{Al}, \mathrm{Ca}, \mathrm{Fe}, \mathrm{Mg}, \mathrm{K}$ and $\mathrm{Na}$ in the prepared solutions was performed by atomic absorption spectrometry using a spectrometer Z-2000 from Hitachi with Zeeman background correction and flame atomization (F-AAS). For the determination of elements such as $\mathrm{Fe}, \mathrm{Mg}, \mathrm{K}$, standard burner was used, fed with a mixture of acetylene and air. Due to high temperature atomization of $\mathrm{Si}, \mathrm{Al}$ and $\mathrm{Ca}$, for determination of this elements high-temperature burner fed a mixture of acetylene and nitrous oxide was used. As a source of radiation single element hollow cathode lamps were used. Calibration was performed using standard solutions. The analytical method was tested by measuring certified reference materials, samples from inter-laboratory comparisons and by standard addition method. Determination of ash in analytical samples were performed according to polish standard PN-G-04512: 1980, and the determination of moisture by PN80/G-04511.

\section{Results and discussion}

Results of investigations of concentrations of individual elements in output coals and concentrates obtained therefrom for the three mines USCB shown in Table 2 and discussed in relation to the various methods of mechanical processing. The results are presented as a weighted average percentage of the analyzed elements in the samples of coal and products of its beneficiation. The amount of mineral matter has been estimated based on the ash content on a Parr formula [6].

Investigated coals are characterized by varying content of mineral matter. The main components are silicon and aluminum, iron and calcium and magnesium are present in 
relatively small amounts. In comparison with other coking coals [7], analyzed coals contains significant amounts of alkaline compounds.

Table 2. The content (\% by weight, dry base) of individual elements in output coals and their concentrates obtained in the coal cleaning process.

\begin{tabular}{|c|c|c|c|c|c|c|c|c|}
\hline \multirow{2}{*}{ Element } & \multirow{2}{*}{ Mineral } & \multirow{2}{*}{ Raw coal } & \multicolumn{2}{|c|}{ Dense medium washer } & \multicolumn{2}{|c|}{ Jig washer } & \multicolumn{2}{|c|}{ Flotation } \\
\hline & & & Feed & Concentrate & Feed & Concentrate & Feed & Concentrate \\
\hline \multirow{3}{*}{$\mathbf{S i}$} & A & 12.55 & 16.28 & 1.17 & 7.90 & 1.40 & 3.18 & 1.39 \\
\hline & $\mathrm{B}$ & 6.30 & 14.78 & 1.19 & 6.99 & 0.62 & 6.11 & 1.86 \\
\hline & $\mathrm{C}$ & 1.97 & 17.44 & 0.49 & 8.43 & 1.10 & 9.05 & 1.40 \\
\hline \multirow{3}{*}{ Al } & A & 4.91 & 7.08 & 0.87 & 4.77 & 1.19 & 2.71 & 0.89 \\
\hline & B & 2.58 & 5.69 & 0.57 & 3.38 & 0.51 & 2.70 & 0.78 \\
\hline & $\mathrm{C}$ & 7.22 & 7.43 & 0.64 & 4.10 & 0.96 & 3.25 & 1.27 \\
\hline \multirow{3}{*}{$\mathbf{C a}$} & A & 0.30 & 1.17 & 0.23 & 0.37 & 0.27 & 1.12 & 0.21 \\
\hline & B & 0.97 & 0.88 & 0.29 & 0.30 & 0.17 & 0.61 & 0.44 \\
\hline & $\mathrm{C}$ & 0.41 & 0.22 & 0.21 & 0.63 & 0.19 & 0.80 & 0.34 \\
\hline \multirow{3}{*}{$\mathbf{F e}$} & A & 1.76 & 4.59 & 1.83 & 1.46 & 0.73 & 0.68 & 0.42 \\
\hline & B & 1.46 & 2.18 & 0.83 & 1.34 & 0.56 & 1.09 & 0.60 \\
\hline & $\mathrm{C}$ & 2.15 & 1.43 & 0.59 & 1.57 & 0.43 & 0.96 & 0.32 \\
\hline \multirow{3}{*}{ Mg } & A & 0.35 & 0.59 & 0.18 & 0.33 & 0.13 & 0.17 & 0.09 \\
\hline & B & 0.38 & 0.51 & 0.12 & 0.25 & 0.08 & 0.07 & 0.12 \\
\hline & $\mathrm{C}$ & 0.31 & 0.26 & 0.05 & 0.38 & 0.06 & 0.31 & 0.08 \\
\hline \multirow{3}{*}{$\mathbf{N a}$} & A & 0.44 & 0.17 & 0.09 & 0.19 & 0.09 & 0.19 & 0.12 \\
\hline & B & 0.09 & 0.11 & 0.06 & 0.09 & 0.05 & 0.11 & 0.07 \\
\hline & C & 0.19 & 0.19 & 0.07 & 0.11 & 0.07 & 0.35 & 0.11 \\
\hline \multirow{3}{*}{$\mathbf{K}$} & $\mathrm{A}$ & 1.19 & 1.38 & 0.09 & 0.89 & 0.11 & 0.44 & 0.12 \\
\hline & B & 0.52 & 1.29 & 0.03 & 0.72 & 0.04 & 0.77 & 0.15 \\
\hline & C & 1.61 & 1.65 & 0.05 & 0.90 & 0.10 & 0.87 & 0.22 \\
\hline \multirow{3}{*}{$\begin{array}{c}\mathbf{A}^{\mathbf{d}} \\
{[\%]}\end{array}$} & $\mathrm{A}$ & 56.8 & 58.0 & 7.70 & 33.3 & 7.90 & 16.8 & 6.3 \\
\hline & B & 22.2 & 48.7 & 4.6 & 28.9 & 4.0 & 22.2 & 8.9 \\
\hline & C & 52.7 & 65.1 & 3.8 & 30.3 & 6.0 & 28.7 & 8.0 \\
\hline \multirow{3}{*}{$\begin{array}{l}\mathbf{M}^{\mathbf{d}} \\
{[\%]}\end{array}$} & A & 57.8 & 62.7 & 8.6 & 36.3 & 8.8 & 18.1 & 7.1 \\
\hline & B & 23.5 & 52.7 & 5.2 & 31.4 & 4.5 & 24.2 & 9.5 \\
\hline & C & 57.1 & 70.4 & 5.2 & 33.0 & 6.8 & 31.2 & 8.7 \\
\hline
\end{tabular}

Differences in the quantitative composition of mineral matter are visible at the stage of primary grain classes separation of raw coal, which can be attributed to differentiated content of mineral matter in examined coals. The feed led to the enrichment of jig washers (grain class $0 \div 20 \mathrm{~mm}$ ) contains half the inorganic material than coal led to the enrichment in dense medium washers (grain class below $20 \mathrm{~mm}$ ), which is reflected in much lower concentration of silicon, aluminum, calcium and iron. Alkali content (especially sodium) do not differ significantly from each other. Despite a lower potassium content in the grain fraction of 0 to $20 \mathrm{~mm}$ (the jig) calculated ratios of potassium to sodium do not differ in the case for both factions of individual mines. As a result of the coal cleaning process in dense medium washers content of inorganic matter decreases dozen times (concentration of total aluminum and silicon). Coal was purified primarily of silicates, aluminosilicates, and the iron compounds (pyrite). The contents of other elements was also reduced significantly. The least noticeable reduction can be seen in the case of sodium, which can be attributed due to crystallization of $\mathrm{NaCl}$ derived from circulating groundwater on grain surface and 
inside them. The loss of sodium is about the same regardless of type of the coal cleaning process in each grain class.

The coal cleaning process in jigs allowed to reduce the content of mineral matter several times. The substantial amounts of silicon, aluminum and potassium were removed from coal. Iron, magnesium and sodium was reduced to a lesser extent.

In the case of flotation (grain class below $0.5 \mathrm{~mm}$ ) the feed has much lower content of mineral matter then feeds to other coal cleaning processes (more than three times lower). However, it has high content of calcium in respect of the feed to the jig washers. Despite the significant reduction of alkali, their content in coal concentrates (after conversion to oxides) is relatively high, considering main use of this type of coal - coke industry. The lowest content of alkali metals was noticed in concentrates dewatered in a centrifuge then in other processes (Table 3).

Table 3. The content of alkali oxides in coals from Upper Silesian Coal Basin mines.

\begin{tabular}{|c|c|c|c|c|c|c|c|c|}
\hline \multirow{2}{*}{$\begin{array}{c}\text { Oxides in coal } \\
{[\% \text { wt.dry mass }]}\end{array}$} & \multirow{2}{*}{ Mineral } & \multirow{2}{*}{ Raw coal } & \multicolumn{2}{|c|}{ Dense medium washer } & \multicolumn{2}{|c|}{ Jig washer } & \multicolumn{2}{|c|}{ Flotation } \\
\hline & & & Feed & Concentrate & Feed & Concentrate & Feed & Concentrate \\
\hline $\mathrm{K}_{2} \mathrm{O}$ & \multirow{3}{*}{ A } & 2,86 & 3,33 & 0,22 & 2,14 & 0,27 & 1,06 & 0,29 \\
\hline $\mathrm{Na}_{2} \mathrm{O}$ & & 1,19 & 0,46 & 0,24 & 0,51 & 0,24 & 0,51 & 0,32 \\
\hline Total: & & 4,05 & 3,79 & 0,46 & 2,65 & 0,51 & 1,57 & 0,61 \\
\hline $\mathrm{K}_{2} \mathrm{O}$ & \multirow{3}{*}{$\mathrm{B}$} & 1,25 & 3,11 & 0,07 & 1,74 & 0,10 & 1,86 & 0,36 \\
\hline $\mathrm{Na}_{2} \mathrm{O}$ & & 0,24 & 0,30 & 0,16 & 0,51 & 0,13 & 0,30 & 0,19 \\
\hline Total: & & 1,49 & 3,41 & 0,23 & 2.25 & 0,23 & 2,16 & 0,55 \\
\hline $\mathrm{K}_{2} \mathrm{O}$ & \multirow{3}{*}{$\mathrm{C}$} & 3,88 & 3,98 & 0,12 & 2,17 & 0,24 & 2,10 & 0,53 \\
\hline $\mathrm{Na}_{2} \mathrm{O}$ & & 0,51 & 0,51 & 0,19 & 0,30 & 0,19 & 0,94 & 0,30 \\
\hline Total: & & 4,39 & 4,49 & 0,31 & 2,47 & 0,43 & 3,04 & 0,83 \\
\hline
\end{tabular}

\section{Conclusion}

Knowledge of the major inorganic element content of coal is important in assessing the usefulness of the material for a specific process. The chemical composition of the mineral matter can constitute the basis for predicting the quality of solid product of coking, combustion and gasification of coal. The process of coal cleaning, in each methods, ie. dense medium washers, jiggers and flotation significantly reduces the content of mineral matter, mainly the content of silicates, aluminosilicates and iron, magnesium and potassium. The highest efficiency shows the process of cleaning in dense medium, but the best quality in terms of metallic elements content has a final product of flotation. Coal concentrates from each cleaning process are characterized by relatively high content of alkali metal compounds, which may be important from the view point of using coal in coke industry.

This paper was prepared as a part of the statutory activity of the Faculty of Energy and Fuels at the AGH University of Science and Technology, No. 11.11.210.213

\section{References}

1. A. Karcz, Karbo; R. 47 nr 10,2002

2. J. Węgiel, H. Machowska, E.Strzednicka; Koks, Smoła, Gaz, vol. XXXVI, nr 5

3. K. Bytnar, T. Dziok, P.Grzywacz, Karbo, tom. LVI, nr 4, 2011

4. A. Strugała; Gospodarka Surowcami Mineralnymi, tom 16, T.15. z.1, s. 5-30,1998

5. J. Kowalczyk, G. Strzelec, Inżynieria mineralna, vol. V, nr 2 (13), 2004

6. A. Karcz; Koksownictwo cz.1, Wydaw. AGH, Kraków 1991

7. K. Bytnar, A. Strugała, Karbo, vol. LII, nr 1, 2007 